\title{
Perceptual processing of nontargets in an attention task
}

\author{
WILLIAM A. JOHNSTON and JOLYNN WILSON \\ University of Utah, Salt Lake City, Utah 84112
}

\begin{abstract}
The capability of nontargets to qualitatively influence the semantic processing of coincident targets was investigated in three experiments. Subjects were aurally presented a series of word pairs and attempted to detect homonymic instances of a predesignated category (e.g., animals). The nontarget with which a target (e.g., ANT) was paired was appropriate (e.g., CRAWLING), inappropriate (e.g., UNCLE), or neutral (e.g., STRAW). Experiments 1 and 2 established that detection of targets can be facilitated by appropriate nontargets and inhibited by inappropriate ones. Thus, nontargets can influence the way in which targets are semantically represented. Experiment 3 showed that this effect is eliminated when subjects are precued as to the ear of entry of targets. Thus, precuing appears to curtail the perceptual processing of nontargets. The data run counter to theories that claim that focused attention does not entail the perceptual suppression of nontargets.
\end{abstract}

Attention is generally considered focused to the extent that a target stimulus receives more processing than concurrent nontarget stimuli. One class of theory localizes this difference in processing at perception: Target stimuli undergo more perceptual processing than nontarget stimuli because of the perceptual suppression of the latter stimuli. Theories of this class include the early-selection theories of Broadbent $(1958,1971)$ and Treisman (1964, 1969). Another class of attention theory conceives of the difference in processing between targets and nontargets as being nonperceptual in nature: Target stimuli are accorded priority by a special attention mechanism that operates on the irrepressible buildup of perceptual data for all concurrent stimuli. Theories of this class include the late-selection theories of Deutsch and Deutsch (1963) and Norman (1968).

The trend in recent years has been away from earlyselection theories and toward late-selection theories (e.g., LaBerge, 1975; Shiffrin \& Schneider, 1977). ${ }^{1}$ The decline in popularity of early-selection theories is based, in part, on empirical indications that nontargets in attention tasks are not suppressed but, rather, undergo deep, semantic analysis (e.g., Corteen \& Wood, 1972; Lewis, 1970; MacKay, 1973; Shiffrin \& Schneider, 1977, Experiment 4). The present research is most closely related to the Lewis (1970) and MacKay (1973) studies.

Lewis (1970) asked subjects to shadow (repeat) words from one of two dichotically presented lists and to ignore words from the other list. The principal finding was that shadowing latency was longer when

This entire research effort, from its inception, has profited from the ideas, comments, and suggestions of Larry Jacoby. We are grateful for his interest and assistance in this research project. Requests for reprints should be addressed to William A. Johnston, Department of Psychology, University of Utah, Salt Lake City, Utah 84112. coincident target (shadowed) and nontarget ("ignored") words were semantically related than when they were unrelated. Since the response to a target word was affected by the meaning of the coincident nontarget word, Lewis concluded that the nontarget words must have undergone semantic analysis. MacKay (1973) asked subjects to shadow an ambiguous message (e.g., "They threw stones at the bank yesterday.") that was presented to one ear and to ignore any words presented to the other ear. The principal finding, as inferred from subsequent recognition tests, was that the interpretation of the shadowed message was biased in the direction of disambiguating words (e.g., "river" or "money") that were presented to the other ear. Since the interpretation of the target message was affected by the semantic properties of nontarget words, MacKay concluded that the nontarget words must have been processed to a semantic level. In general, this entire line of research reduces the plausibility of early-selection theories by showing that attention to targets does not necessarily prevent the semantic analysis of nontargets.

The present studies extend this line of research. Subjects listened to a series of word pairs and attempted to detect instances of a category such as "articles of clothing." Experiments 1 and 2 sought to determine whether the detectability of a homonymic target word such as "socks" can be either enhanced by a coincident nontarget word such as "smelly" (appropriate nontarget) or hindered by one such as "punches" (inappropriate nontarget). These studies were intended to show that the semantic properties of nontargets can affect the detectability of targets by controlling how they are represented perceptually. Experiment 3 attempted to discriminate between early- and late-selection theories empirically by determining whether a manipulation that increases the overall detectability of targets also reduces the effects on target detectability of appropriate and 
inappropriate nontargets. The reasoning behind Experiment 3 will be developed after Experiments 1 and 2 are presented.

\section{EXPERIMENT 1}

\section{Method}

Subjects. The subjects were 36 male and female students at the University of Utah. They were recruited from introductory psychology classes and received credit toward a higher grade for their participation.

Procedures. Subjects performed a target-detection task on a succession of nine different lists of word pairs. A list consisted of 81 word pairs, 9 of which contained a target word (i.e., an instance of the target category). The word pairs were presented at the rate of one every $1.5 \mathrm{sec}$. The interlist interval was $15 \mathrm{sec}$. A target category was announced $10 \mathrm{sec}$ in advance of each list. The nine target words in a list were homonyms with at least two distinct meanings, only one of which fell within the domain of the target category. Targets were presented at the rate of one in every successive block of nine pairs. Placement of targets in blocks was random, with the restriction that there be at least four word pairs between any two targets.

The manipulation of interest was the nature of the nontarget word with which a target word was paired. An appropriate nontarget was related to the target meaning of the target word, an inappropriate nontarget was related to a different meaning of the target word, and a neutral nontarget was not related to the target word. All three kinds of nontargets were represented, in random order, in each successive set of three targets in a list. Moreover, across subjects, all three kinds of nontargets were represented for each target word. The full set of target and nontarget words used in the experiment is provided in the Appendix. Nine different orders of both lists and target words within lists were represented across subjects.

The subjects served individually in a sound-deadened cubicle. The prerecorded lists were played to subjects from a tape recorder through an amplifier and over stereophonic earphones. Presentation of the word pairs was binaural, rather than dichotic, in that both words in a pair were played to both of a subject's ears. Subjects were instructed to repeat aloud every target word that they detected; their responses were tape-recorded and later scored for accuracy. The task may be considered a dividedattention one, in that subjects had to process both members of each pair in order to detect targets.

\section{Results and Discussion}

Across the nine lists, each subject received 27 targets for each type of nontarget. The unit of analysis was the number of targets detected. These units, pooled across subjects and converted into percentages, are summarized in the first row of Table 1. Type of nontarget attained statistical significance in an analysis of variance of these data $[F(2,70)=4.05$, MSe $=.48] .^{2}$ A Newman-Keuls test confirmed the pattern shown in Table 1. Relative to neutral nontargets, inappropriate nontargets reduced the likelihood of detecting targets but appropriate nontargets had no effect on target detections. Although the inhibitory effect of inappropriate nontargets was small in absolute terms, it was highly consistent across subjects.

The inhibitory effect of inappropriate nontargets is consistent with the findings of Lewis (1970) and MacKay (1973) in indicating that nontargets in an attention task undergo semantic analysis. However, a symmetrical facilitative effect of appropriate nontargets was not obtained. One possible reason for the lack of a facilitative effect of appropriate nontargets is that they were often mistaken for targets. Indeed, $6.5 \%$ of appropriate nontargets were actually given as responses in lieu of the targets with which they were paired. This target-nontarget confusion factor was successfully reduced in Experiment 2 by changing from binaural presentation of word pairs to dichotic presentation.

\section{EXPERIMENT 2}

\section{Method}

Experiment 2 was a precise replication of Experiment 1 except that presentation of word pairs was dichotic (one word to each ear) rather than binaural and the number of subjects was 45 rather than 36 . The target words in a list alternated randomly between the two ears. Thus, divided attention was still required.

\section{Results and Discussion}

The data are summarized in the second row of Table 1. The results deviated from those of Experiment 1 in two ways: The overall rate of target detection was increased from $41 \%$ to $54 \%$, and both a facilitative effect of appropriate nontargets and an inhibitory effect of inappropriate nontargets were obtained. Type of nontarget attained significance in an analysis of variance of these data $[F(2,88)=7.09, \mathrm{MSe}=.54]$. Newman-Keuls tests confirmed that all three types of nontargets differed from each other in terms of accuracy of target detection. Again, the differences were small in magnitude but highly consistent across subjects.

Experiment 2 extends the findings of Experiment 1 by indicating that the semantic analysis of nontargets can enhance, as well as impede, the detection of targets. The emergence of a facilitative effect of appropriate nontargets was accompanied by a reduction in the rate

Table 1

Percent of Targets Detected in Experiments 1-3 as a Function of Type of Nontarget

Type of Nontarget

\begin{tabular}{|c|c|c|c|c|c|c|c|}
\hline $\begin{array}{l}\text { Experi- } \\
\text { ment }\end{array}$ & $\mathrm{N}$ & $\begin{array}{l}\text { Attention } \\
\text { Condition }\end{array}$ & $\begin{array}{l}\text { Appro- } \\
\text { priate }\end{array}$ & & Neutral & & $\begin{array}{c}\text { Inappro- } \\
\text { priate }\end{array}$ \\
\hline 1 & 35 & Divided, Binaural & 42 & $=$ & 43 & $>$ & 39 \\
\hline 2 & 45 & Divided, Dichotic & 57 & $>$ & 54 & $>$ & 51 \\
\hline 3 & 27 & Divided, Dichotic & 67 & $>$ & 55 & $>$ & 47 \\
\hline 3 & 27 & Focused, Dichotic & 74 & $=$ & 72 & $=$ & 72 \\
\hline
\end{tabular}

Note - The $>$ and $=$ signs indicate whether or not two percentages were statistically different $(p<.05)$. 
at which these nontargets were "detected" in lieu of targets: $2.6 \%$ in Experiment 2 compared with $6.5 \%$ in Experiment 1. As a composite, the data of Experiments 1 and 2 show that the perceptual representations of target stimuli can be affected qualitatively by the nontargets with which they are paired. Experiment 3 was designed to assess the implications of this phenomenon for theories of attention.

\section{EXPERIMENT 3}

The third experiment attempted to discriminate empirically between early- and late-selection theories of attention by orthogonally manipulating type of nontarget and precuing of targets. Ninio and Kahneman (1974) examined the effect of precuing on detectability of targets in a dichotic-listening task. In a precuing or focused-attention condition, targets (animal names) were confined to just one ear and subjects were so informed. In a divided-attention condition, targets were randomly distributed between the two ears, and subjects were so informed. Speed and accuracy of target detection were higher in the focused-attention condition than in the divided-attention condition.

Early- and late-selection theories provide different interpretations of the precuing effect. Early-selection theories would argue that precuing enhances the detectability of targets by reducing the perceptual processing of nontargets. Late-selection theories would argue that precuing enhances the selection precision or automaticity of the attention mechanism but has no effect on the amount of perceptual processing of nontargets. An empirical decision between these two classes of theory could be rendered by examining the effect of precuing on the amount of perceptual processing of nontargets.

Amount of perceptual processing of nontargets was measured in terms of the magnitude of the effects of appropriate and inappropriate nontargets. The logic behind this technique was as follows: If the component effects of type of nontarget, like the Lewis (1970) and MacKay (1973) effects, reflect the perceptual processing of nontargets, then variations in the magnitude of these effects may reflect variations in the amount of perceptual processing of nontargets. Within the context of this logic, then, the two classes of attention theory make different predictions. According to early-selection theory, precuing should reduce the effects of appropriate and inappropriate nontargets. According to lateselection theory, precuing should not alter these effects.

\footnotetext{
Method

A 2 by 3 design was used in which type of nontarget was manipulated under both focused-attention and divided-attention conditions. Each of the latter conditions was administered to a group of 27 students.

The divided-attention condition was, in essence, a replication of Experiment 2. That is, list presentation was dichotic and targets were randomly distributed between the two ears. However, in an effort to increase the effect of type of target, only the
}

four target categories for which that effect was most pronounced in Experiment 2 were used in Experiment 3. These categories were "body parts," "animals," "edibles," and "clothing." In addition, each list was increased in length from 81 to 324 word pairs. Targets still occurred at the rate of 1 in every nine word pairs, but 27 of the targets in each list were new "filler" targets that were unrelated to the nontargets with which they were paired. The remaining nine targets in each list were the ones used in Experiments 1 and 2 and with respect to which type of nontarget was manipulated.

The lists were identically constructed for the focused-attention condition, except that all targets were presented to the left ear. The left ear was chosen for target presentation so that appropriate and inappropriate nontargets would enter the right ear and be represented predominantly in the left hemisphere. This procedure was expected to increase the opportunity for an effect of type of nontarget in the focused-attention condition and, thus, for the confirmation of late-selection theory. Subjects in each condition were instructed as to the actual distribution of targets between the two ears and were encouraged to distribute their attention accordingly.

\section{Results and Discussion}

The results are summarized in the third (divided attention) and fourth (focused attention) rows of Table 1. All three experimental sources of variance attained statistical significance in an analysis of variance of these data: precuing $[\mathrm{F}(1,52)=30.77, \mathrm{MSe}=5.20]$, type of nontarget $[\mathrm{F}(2,52)=13.89, \mathrm{MSe}=1.74]$, and their interaction $[F(2,52)=8.10, M S e=1.89]$. The precuing effect replicates the finding of Ninio and Kahneman (1974): Target-detection accuracy was higher under focused attention than under divided attention. The effect of type of nontarget was the same as that found in Experiment 2: Relative to neutral nontargets, accuracy of target detection was enhanced by appropriate nontargets and inhibited by inappropriate nontargets.

The interaction is of principal interest. A NewmanKeuls test revealed that the effect of type of nontarget was restricted to the divided-attention condition. Moreover, the effect in that condition was larger, in absolute terms, than it was in either of the first two experiments. Evidently, the list-selection procedure succeeded in accentuating the effect of type of nontarget. Nonetheless, this large effect was eliminated by precuing subjects as to the ear of entry of targets.

Despite the fact that the average rate of target detection was well below $100 \%$ in the focused-attention condition, one might argue that an effect of type of nontarget in that condition was prevented by a performance ceiling. This possibility was examined by breaking both the focused-attention and divided-attention groups into bottom, middle, and top thirds in terms of the overall rate of target detection. The data for each subgroup are summarized in Table 2. One-way analyses of variance revealed that the effect of type of nontarget was significant in none of the focused-attention subgroups $[\mathrm{F}(2,16)=1.87, \mathrm{MSe}=2.57$, for the bottom one-third; $F=1.26, \mathrm{MSe}=3.82$, for the middle onethird; $\mathrm{F}=1.79, \mathrm{MSe}=.58$, for the top one-third] but was significant in all of the divided-attention subgroups 
Table 2

Effect of Type of Nontarget Under Focused and Divided Attention in Experiment 3 as a Function of Overall Performance Level of Subjects (Bottom, Middle, and Top)

\begin{tabular}{lcccc}
\hline & \multicolumn{4}{c}{ Type of Nontarget } \\
\cline { 2 - 5 } $\begin{array}{c}\text { Performance } \\
\text { Level }\end{array}$ & $\begin{array}{c}\text { Appro- } \\
\text { priate }\end{array}$ & Neutral & $\begin{array}{c}\text { Inappro- } \\
\text { priate }\end{array}$ & $\begin{array}{c}\text { Mean } \\
\text { Level }\end{array}$ \\
\hline & \multicolumn{4}{c}{ Divided Attention Condition } \\
Bottom & 57 & 42 & 36 & 45 \\
Middle & 68 & 54 & 47 & 56 \\
Top & 76 & 68 & 58 & 67 \\
& & Focused Attention Condition \\
Bottom & 63 & 60 & 59 & 61 \\
Middle & 71 & 70 & 74 & 72 \\
Top & 88 & 86 & 82 & 85 \\
\hline
\end{tabular}

Note-Bottom $=$ lower third $(N=9)$ of subjects in terms of overall detection accuracy; middle $=$ middle third; top $=$ upper third.

$[\mathrm{F}=15.51, \mathrm{MSe}=1.02$, for the bottom one-third; $\mathrm{F}=6.75, \mathrm{MSe}=2.08$, for the middle one-third; $\mathrm{F}=7.12$, $\mathrm{MSe}=1.41$, for the top one-third] .

It is important to note in Table 2 that the mean level of target-detection accuracy was higher in the top subgroup of divided-attention subjects than in the bottom subgroup of focused-attention subjects. Nonetheless, the effect of type of nontarget was reliable only in the case of the former subgroup. Hence the . important interaction between precuing and type of nontarget cannot be attributed to a mensural ceiling under focused attention. This interaction is consistent with early-selection theory but difficult to reconcile with late-selection theory.

\section{GENERAL DISCUSSION}

The present data extend prior findings in two ways. First, they establish further that nontarget stimuli can be processed to a semantic level. As in the Lewis (1970) and MacKay (1973) studies, processing of target stimuli was affected by the semantic properties of nontargets. The present results extend the boundaries of the prior effects of type of nontarget by demonstrating that the semantic properties of nontargets can affect the accuracy, as well as latency, of target detection and can enhance, as well as inhibit, target detection. Thus, nontargets can have a qualitative effect on the perceptual processing of the targets with which they are paired.

The second way in which the present research extends prior findings is by indicating that the amount of semantic processing of nontargets is not invariant. The component effects of type of nontarget disappeared when targets were made more detectable by the precuing manipulation. Similar findings have been obtained in other recent studies. Treisman, Squire, and Green (1974) found that the Lewis (1970) effect dissipates over the course of a dichotic-listening trial. Johnston and Heinz
(1979) found that the Lewis effect is reduced as targets and nontargets are made more discriminable physically. Finally, Underwood (1976) examined a visual version of the Lewis effect and found it to be reduced when subjects are precued as to the spatial position of the target in the stimulus display. ${ }^{3}$ If the effect of type of nontarget reflects the perceptual processing of nontargets, then the present and other recent data indicate that the amount of this processing is variable. Perceptual processing of nontargets appears to be curtailed, or suppressed, as targets are rendered more detectable as a function of such variables as practice, physical discriminability, and precuing.

Proponents of late-selection theory might argue that the observed variations in the effects of nontargets on responses to targets reflect variations in amount of nonperceptual, rather than perceptual, processing of nontargets. Indeed, variability in the selection precision of the attention mechanism has been explicitly built into the theories of LaBerge (1975) and Shiffrin and Schneider (1977). Under some conditions, the "attention director" has to search through all of the perceptual data for that portion that represents the target. Under other conditions, the attention director "automatically detects" the target representation. Perhaps responses to targets are affected by the semantic (and other) properties of nontargets only when conditions force the attention mechanism to process nontargets in its "controlled search" for targets.

As convincing as this nonperceptual line of reasoning might be, it is inconsistent with the empirical attack that late-selection theorists have launched against earlyselection theory. Specifically, the case against early. selection theory has rested primarily on the argument that the findings of Lewis (1970), MacKay (1973), and others reflect the full perceptual processing of nontargets. Late-selection theorists appear to be left with the following choice: Either interpret Lewis-like effects in terms of the perceptual processing of nontargets and admit that this processing is suppressible, or interpret these effects in terms of the nonperceptual processing of nontargets and dismiss their empirical case against early-selection theories. In either event, early-selection theories of attention must be considered to remain a viable alternative to late-selection theories.

\section{REFERENCE NOTE}

1. Dawson, M. E., \& Schell, A. M. Electrodermal responses to attended and nonattended significant stimuli. Paper presented at the meeting of the Society for Psychophysiological Research, Cincinnati, October 1979

\section{REFERENCES}

Broadbent, D. E. Perception and communication. London: Pergamon Press, 1958.

Broadbent, D. E. Decision and stress. New York: Academic Press, 1971 
Corteen, R. S., \& Wood, B. Automatic responses to shock associated words in an unattended channel. Journal of Experimental Psychologv, 1972, 94, 308-313.

Drutsch, J. A., \& Deutsch, D. Attention: Some theoretical considerations. Psychological Review, 1963, 70, 80-90.

Johnston, W. A., \& Heinz, S. P. Depth of nontarget processing in an attention task. Journal of Experimental Psychology: Human Perception and Performance, 1979, 5, 168-175.

LABrRGE, D. Acquisition of automatic processing in perceptual and associative learning. In P. M. A. Rabbitt \& S. Dornic (Eds.), Attention and performance $V$. New York: Academic Press, 1975

LEWIS, J. L. Semantic processing of unattended messages using dichotic listening. Journal of Experimental Psychology, 1970, 85, 225-228.

MacKay, D. G. Aspects of the theory of comprehension, memory, and attention. Quarterly Journal of Experimental Psychology, 1973. 25, 22-40.

Ninio, A., \& Kahneman, D. Reaction time in focused and divided attention. Journal of Experimental Psychology, 1974, 103, 394-399

Norman, D. A. Toward a theory of memory and attention. Psuchological Review, 1968, 75, 522-536.

Shiffrin, R. M., \& Schneider, W. Controlled and automatic human information processing: II. Perceptual learning, auto- matic attending, and a general theory. Psychological Review, $1977,84,127-190$.

Treisman, A. M. Verbal cues, language and meaning in selective attention. American Journal of Psychology, 1964, 77, 206-218.

'Treisman, A. M. Strategies and models of selective attention. Psychological Review, 1969, 76, 282-299.

Treisman, A. M., Squire, R., \& Green, J. Semantic processing in dichotic listening? A replication. Memory \& Cognition, 1974 , 2, 641-646.

UNDERWOOD, G. Semantic interference from unattended printed words. British Journal of Psychology, 1976, 67, 327-338.

\section{NOTES}

1. The term "late selection" does not accurately describe these recent theories because they allow for the attention director to operate in parallel with, as well as after, perceptual processing of targets and nontargets. However, nontargets are assumed to run their full perceptual course in either case.

2 . The level of significance was set at $p<.05$ in all of the statistical analyses referred to in this report.

3. Recent data (e.g., Dawson \& Schell, Note 1) also call into question other empirical indicants of the uniformly deep perceptual processing of nontargets (e.g., Corteen \& Wood, 1972).

Appendix

Target Categories, Homonyms, and the Nontargets of each Type (Appropriate, Inappropriate, and Neutral) Used in Experiments 1-3

\begin{tabular}{|c|c|c|c|c|}
\hline \multirow{2}{*}{$\begin{array}{c}\text { Target } \\
\text { Category }\end{array}$} & \multirow{2}{*}{$\begin{array}{c}\text { Homonymic } \\
\text { Target }\end{array}$} & \multicolumn{3}{|c|}{ Type of Nontarget } \\
\hline & & Appropriate & Neutral & Inappropriate \\
\hline Body Parts & $\begin{array}{l}\text { arms } \\
\text { head } \\
\text { calf } \\
\text { foot } \\
\text { waist } \\
\text { chest } \\
\text { hair } \\
\text { neck } \\
\text { nose }\end{array}$ & $\begin{array}{l}\text { sleeves } \\
\text { bald } \\
\text { muscular } \\
\text { shoe } \\
\text { belt } \\
\text { hairy } \\
\text { comb } \\
\text { choke } \\
\text { kleenex }\end{array}$ & $\begin{array}{l}\text { plant } \\
\text { time } \\
\text { stapler } \\
\text { cigar } \\
\text { fountain } \\
\text { ruler } \\
\text { sun } \\
\text { travel } \\
\text { arrest }\end{array}$ & $\begin{array}{l}\text { weapons } \\
\text { leader } \\
\text { cow } \\
\text { inch } \\
\text { squander } \\
\text { treasure } \\
\text { rabbit } \\
\text { kiss } \\
\text { understands }\end{array}$ \\
\hline Household Items & $\begin{array}{l}\text { sink } \\
\text { hamper } \\
\text { range } \\
\text { bureau } \\
\text { chest } \\
\text { cabinet } \\
\text { counter } \\
\text { vanity } \\
\text { iron }\end{array}$ & $\begin{array}{l}\text { wash } \\
\text { dirty clothes } \\
\text { electric } \\
\text { bedroom } \\
\text { storage } \\
\text { medicine } \\
\text { kitchen } \\
\text { make-up } \\
\text { steam }\end{array}$ & $\begin{array}{l}\text { green } \\
\text { tortoise } \\
\text { contract } \\
\text { sale } \\
\text { cord } \\
\text { jacket } \\
\text { nest } \\
\text { degree } \\
\text { fish }\end{array}$ & $\begin{array}{l}\text { titanic } \\
\text { impede } \\
\text { ranch } \\
\text { federal } \\
\text { breast } \\
\text { government } \\
\text { geiger } \\
\text { selfish } \\
\text { ore }\end{array}$ \\
\hline Child's Toys & $\begin{array}{l}\text { train } \\
\text { blocks } \\
\text { ball } \\
\text { scrabble } \\
\text { jacks } \\
\text { tag } \\
\text { marble } \\
\text { top } \\
\text { swing }\end{array}$ & $\begin{array}{l}\text { choo-choo } \\
\text { wooden } \\
\text { bouncing } \\
\text { words } \\
\text { recess } \\
\text { touch } \\
\text { round } \\
\text { spinning } \\
\text { playground }\end{array}$ & $\begin{array}{l}\text { robin } \\
\text { hem } \\
\text { smoke } \\
\text { hour } \\
\text { family } \\
\text { river } \\
\text { link } \\
\text { paper } \\
\text { chimney }\end{array}$ & $\begin{array}{l}\text { teach } \\
\text { barricades } \\
\text { banquet } \\
\text { quarrel } \\
\text { flat tires } \\
\text { price } \\
\text { statue } \\
\text { bottom } \\
\text { sway }\end{array}$ \\
\hline Animals & $\begin{array}{l}\text { duck } \\
\text { ant } \\
\text { swallow } \\
\text { turkey } \\
\text { fly } \\
\text { badger } \\
\text { bear } \\
\text { steer } \\
\text { deer }\end{array}$ & $\begin{array}{l}\text { quacking } \\
\text { crawling } \\
\text { nesting } \\
\text { gobble } \\
\text { buzz } \\
\text { caged } \\
\text { hibernate } \\
\text { roundup } \\
\text { antler }\end{array}$ & $\begin{array}{l}\text { movie } \\
\text { straw } \\
\text { spoon } \\
\text { ash } \\
\text { wax } \\
\text { violin } \\
\text { luck } \\
\text { jam } \\
\text { amber }\end{array}$ & $\begin{array}{l}\text { dodge } \\
\text { uncle } \\
\text { drink } \\
\text { india } \\
\text { pilot } \\
\text { harass } \\
\text { naked } \\
\text { guide } \\
\text { sweetheart }\end{array}$ \\
\hline
\end{tabular}




\begin{tabular}{|c|c|c|c|c|}
\hline \multirow{2}{*}{$\begin{array}{c}\text { Target } \\
\text { Category }\end{array}$} & \multirow{2}{*}{$\begin{array}{c}\text { Homony mic } \\
\text { Target }\end{array}$} & \multicolumn{3}{|c|}{ Type of Nontarget } \\
\hline & & Appropriate & Neutral & Inappropriate \\
\hline Beverages & $\begin{array}{l}\text { punch } \\
\text { tea } \\
\text { soda } \\
\text { champagne } \\
\text { scotch } \\
\text { shake } \\
\text { squirt } \\
\text { tab } \\
\text { pop }\end{array}$ & $\begin{array}{l}\text { hawaiian } \\
\text { iced } \\
\text { orange } \\
\text { bubbly } \\
\text { on rocks } \\
\text { strawberry } \\
\text { thirst } \\
\text { diet } \\
\text { bottle }\end{array}$ & $\begin{array}{l}\text { leech } \\
\text { slant } \\
\text { fish } \\
\text { slant } \\
\text { fox } \\
\text { snail } \\
\text { scale } \\
\text { snake } \\
\text { dog }\end{array}$ & $\begin{array}{l}\text { hit } \\
\text { golf } \\
\text { baking } \\
\text { illinois } \\
\text { irish } \\
\text { tremble } \\
\text { small fry } \\
\text { hunter } \\
\text { mom }\end{array}$ \\
\hline Clothing & $\begin{array}{l}\text { slip } \\
\text { socks } \\
\text { pants } \\
\text { shorts } \\
\text { suits } \\
\text { cords } \\
\text { coat } \\
\text { hose } \\
\text { belt }\end{array}$ & $\begin{array}{l}\text { lacy } \\
\text { smelly } \\
\text { bell-bottom } \\
\text { boxer } \\
\text { men's } \\
\text { boy's } \\
\text { sheepskin } \\
\text { snag } \\
\text { waist }\end{array}$ & $\begin{array}{l}\text { store } \\
\text { tuesday } \\
\text { lens } \\
\text { bus } \\
\text { carrot } \\
\text { barber } \\
\text { dump } \\
\text { grain } \\
\text { thrush }\end{array}$ & $\begin{array}{l}\text { slide } \\
\text { punches } \\
\text { dog } \\
\text { fusebox } \\
\text { satisfies } \\
\text { electric } \\
\text { paint } \\
\text { garden } \\
\text { slug }\end{array}$ \\
\hline Money & $\begin{array}{l}\text { quarter } \\
\text { franc } \\
\text { check } \\
\text { pound } \\
\text { change } \\
\text { cent } \\
\text { crown } \\
\text { bucks } \\
\text { mark }\end{array}$ & $\begin{array}{l}\text { bicentennial } \\
\text { paris } \\
\text { signed } \\
\text { british } \\
\text { pocket } \\
\text { ten } \\
\text { denmark } \\
\text { wallet } \\
\text { germany }\end{array}$ & $\begin{array}{l}\text { wrestle } \\
\text { wednesday } \\
\text { bone } \\
\text { senate } \\
\text { artery } \\
\text { column } \\
\text { viola } \\
\text { celery } \\
\text { lift }\end{array}$ & $\begin{array}{l}\text { football } \\
\text { honest } \\
\text { mate } \\
\text { ounce } \\
\text { novelty } \\
\text { perfume } \\
\text { headware } \\
\text { bronco } \\
\text { twain }\end{array}$ \\
\hline Edibles & $\begin{array}{l}\text { rolls } \\
\text { nuts } \\
\text { steak } \\
\text { ham } \\
\text { chili } \\
\text { meat } \\
\text { fudge } \\
\text { shrimp } \\
\text { dessert }\end{array}$ & $\begin{array}{l}\text { dinner } \\
\text { salted } \\
\text { juicy } \\
\text { smoked } \\
\text { spicy } \\
\text { butcher } \\
\text { homemade } \\
\text { broiled } \\
\text { sweet }\end{array}$ & $\begin{array}{l}\text { lazy } \\
\text { bridle } \\
\text { path } \\
\text { part } \\
\text { thursday } \\
\text { grass } \\
\text { grow } \\
\text { joint } \\
\text { owl }\end{array}$ & $\begin{array}{l}\text { royce } \\
\text { crazy } \\
\text { tent } \\
\text { actor } \\
\text { freezing } \\
\text { introduce } \\
\text { cheat } \\
\text { pip-squeak } \\
\text { abandon }\end{array}$ \\
\hline Girls' Names & $\begin{array}{l}\text { jean } \\
\text { may } \\
\text { carrie } \\
\text { mary } \\
\text { carol } \\
\text { ginger } \\
\text { florence } \\
\text { rose } \\
\text { sandy }\end{array}$ & $\begin{array}{l}\text { harlow } \\
\text { west } \\
\text { fisher } \\
\text { tyler moore } \\
\text { burnett } \\
\text { rogers } \\
\text { nightingale } \\
\text { kennedy } \\
\text { dennsion }\end{array}$ & $\begin{array}{l}\text { leaf } \\
\text { shop } \\
\text { key } \\
\text { apple } \\
\text { friday } \\
\text { panama } \\
\text { paper } \\
\text { piano } \\
\text { skate }\end{array}$ & $\begin{array}{l}\text { chromosome } \\
\text { month } \\
\text { tote } \\
\text { wed } \\
\text { christmas } \\
\text { spice } \\
\text { italy } \\
\text { thorn } \\
\text { beach }\end{array}$ \\
\hline
\end{tabular}

(Received for publication February 18, 1980; revision accepted April 18, 1980.) 